ROCZNIKI HUMANISTYCZNE

Tom LXVIII, zeszyt $3-2020$

DOI: http://dx.doi.org/10.18290/rh20683-6

JAN SKARBEK-KAZANECKI

\title{
PROBLEM AUTENTYCZNOŚCI CORPUS THEOGNIDEUM W ŚWIETLE HISTORII JEGO TRANSMISJI: MANUSKRYPTY I PIERWSZE EDYCJE KRYTYCZNE*
}

Corpus Theognideum, czyli zbiór elegii przypisywanych Teognisowi z Megary, przetrwał do czasów współczesnych za sprawą bezpośredniego przekazu rękopiśmiennego, co - jak stwierdza Krystyna Bartol - „w przypadku wczesnogreckiej liryki jest rzadkością" ${ }^{1}$, jest on także największym zachowanym zbiorem starożytnej greckiej poezji. Stanowi mimo to, obok Iliady i Odysei Homera, najczęściej podważane pod względem jedności autorskiej dzieło antycznej tradycji ${ }^{2}$. Na gruncie badań tekstualnych trudno zaś podjąć trud interpretowania danego utworu bez możliwości odniesienia się do jego

Mgr JAN SKARBEK-KAZANECKI - doktorant w Katedrze Filologii Klasycznej i student filozofii Uniwersytetu Łódzkiego, ul. Pomorska 171/173, 90-236 Lódź, e-mail: jan.skarbek-kazanecki@ci.edu.pl; ORCID: 0000-0002-4127-4070.

* Niniejszy tekst stanowi rozwinięcie badań przedstawionych w pracy magisterskiej pt. „Problem jedności autorskiej Corpus Theognideum" (promotor pracy: dr hab. Hanna Zalewska-Jura), obronionej w czerwcu 2018 r. na Uniwersytecie Łódzkim.

${ }^{1}$ Krystyna BARTOL, „Elegia okresu archaicznego,” w Literatura Grecji Starożytnej, t. I, red. Henryk Podbielski (Lublin: Towarzystwo Naukowe KUL, 2005), 341; podobnie Carlos SCHRADER, Concordantia Theognidea (Hildesheim-Zürich-New York: Olms-Weidmann, 2002), 1.

${ }^{2}$ Warto wymienić kluczowe problemy związane z formą, w jakiej zachowały się elegie przypisywane Teognisowi: różnice w tematyce poszczególnych elegii, zbieżności z tekstami innych poetów (Solona, Mimnermosa, Tyrtajosa) czy fakt przypisania przez tradycję pośrednią niektórych ustępów korpusu innym autorom (np. Euenosowi); nawiązania do wydarzeń, które miały miejsce na długo po sugerowanym przez źródła historyczne bądź analizy filologiczne okresie powstania dzieła, występowanie różnych zwrotów inwokacyjnych; niektóre fragmenty są bardzo krótkie, podczas gdy inne przypominają raczej ustępy ze zwartego tekstu poetyckiego, niekiedy także wersy powtarzają się; Corpus Theognideum zachował się ponadto w dwóch księgach, z czego księga druga, zawierająca utwory w przeważającym stopniu erotyczne, przekazana została w jednym, najstarszym manuskrypcie (nt. zob. niżej). 
autora $^{3}$, jeszcze zaś trudniej wyobrazić sobie badanie „świata przedstawionego" w wypadku dzieła utkanego z pojedynczych, zebranych wbrew intencjom twórców wyrywków prac różnych poetów. Chcąc porównać różne ustępy tekstu czy wydobyć warstwę ideową stojącą za poszczególnymi jego fragmentami należy założyć, że istnieje jeden, względnie kilku autorów działających w podobnym miejscu i czasie, zanurzonych w jednym kontekście społecznym ${ }^{4}$.

Pytanie o autora i jedność autorską tekstu do lat osiemdziesiątych XX wie$\mathrm{ku}$ stanowiło centralne zagadnienie $\mathrm{w}$ badaniach nad Corpus Theognideum. Sytuacja uległa zmianie wraz z przełomem w sposobie rozumienia archaicznej liryki greckiej, czyli z tzw. zwrotem performatywno-pragmatycznym ${ }^{5}$ : uświadomieniem sobie przez badaczy oralnego charakteru poezji tego okresu - zapamiętywanej, nie zaś spisywanej, jak pisze Giovanni Cerri, przetrwałej dzięki ponawianym prezentacjom i traktowanej nie jako zamknięty tekst, którego autorski zamysł należałoby uszanować i zachować niezmienionym, a raczej

\footnotetext{
${ }^{3}$ Jak pisze Krzysztof UniŁowski, Granice nowoczesności. Proza polska i wyczerpanie modernizmu (Katowice: Uniwersytet Śląski, 2006), 64: „mnogie teksy podważają i uchylają scalającą rolę instancji podmiotowej”. Przyznają to nawet ci badacze, którzy deprecjonują perspektywę nakierowaną na autora i uznają, że w toku interpretacji tekst jest autonomiczny, oderwany od źródłowych intencji twórcy - np. Paul Ricoeur, „Zadanie hermeneutyki,” przeł. Piotr Graff, w IDEM, Język, tekst, interpretacja (Warszawa: Państwowe Wydawnictwo Naukowe, 1989), 206; Hans-Georg GADAMER, „Poezja i interpretacja”, przeł. Małgorzata Łukasiewicz, Pamiętnik Literacki 68, nr 4 (1977): 301-303; Roland BARTHES, „Śmierć autora”, przeł. Michał Paweł Markowski, Teksty Drugie 1-2(1999): 247-251. Zob. jednak próbę dekonstrukcji kategorii autora, także jako instancji scalającej tekst, w: Michel FoucAult, „What Is an Author?”, przeł. Josué V. Harari, w Textual Strategies: Perspectives in Post- Structuralist Criticism, red. Josué V. Harari (Ithaca, N.Y.: Cornell, 1979), 141-160 wraz z uwagami Aleksandra Nehamasa, „What an Author Is”, The Journal of Philosophy 83, nr 11(1986): 685-691.

${ }^{4}$ Pogląd, że Corpus Theognideum stanowi wytwór jednolitej tradycji, zbiór powstałych w podobnym miejscu i czasie elegii, a tym samym utwór spójny światopoglądowo, przyświeca autorom rewolucyjnej dla badan nad tym zbiorem monografii Theognis of Megara. Poetry and the Polis, red. Thomas J. Figueira, Gregory Nagy (Baltimore: Johns Hopkins University Press, 1984). Podobnie interpretował elegie Corpus Theognideum Massimo Vetta, włoski uczony powiązał je jednak nie z miastem Megarą i ideologią tej polis, a z bankietami arystokratów, IDEM, "Commento", w Teognide, Libro Secondo. Introduzione, testo critico, traduzione e commento, ed. Massimo Vetta (Roma: Edizioni dell'Ateneo, 1980), 59-60. Obie publikacje stanowią wyraz szerszej tendencji w badaniach poezji archaicznej, ,zwrotu performatywno-pragmatycznego”, o którym niżej.

5 Jerzy DANIELEwICZ, „Wprowadzenie”, w Antologia liryki hellenistycznej, red. Jerzy Danielewicz (Warszawa: Wydawnictwo Naukowe PWN, 2018), 12-14. Na temat performatywnego charakteru poezji archaicznej oraz roli sympozjów - tła kontekstualnego i przestrzeni wykonawczej elegii - piszę w artykule „Grecki symposion jako przestrzeń dyskursu filozoficznego: Ksenofanes i krytyka tradycji poetyckiej," Tekstualia 56, nr 1(2019): 35-52.
} 
jako wspólne „dziedzictwo” (un patrimonio comune), ze swobodą powtarzane, $\mathrm{z}$ uwagi na stale zmieniające się okoliczności i konteksty wykonawcze ${ }^{6}$.

Zamiarem tekstu nie jest polemika z powyższym modelem interpretacyjnym, nie zamierzam także rozstrzygać kilkusetletniej wątpliwości związanej $\mathrm{z}$ autorstwem zbioru ${ }^{7}$; zamiast tego chciałbym przyjrzeć się historii „kwestii teognidejskiej”, za punkt odniesienia przyjmując historię transmisji tekstu. Jak pisał Hans-Georg Gadamer, ,[h]ermeneutyczną prawdą, której [...] nie należy pomijać, jest to, że historia oddziaływania należy do samej rzeczy"8. Dla Gadamera, bodaj najważniejszego przedstawiciela współczesnej hermeneutyki, wszelkie badanie historyczne musi opierać się nie tylko na świadomości różnicy czasowej dzielącej interpretatora od badanego tekstu, lecz także na uprzytomnieniu sobie przez badacza uwikłania w oddziałującą na niego historię. Celem artykułu jest stworzenie rozumianego w ten sposób horyzontu hermeneutycznego uwzględniającego historię transmisji oraz pierwszych badań poświęconych Theognidei, ukazującego „gdzie” i „kiedy” sporu o Teognisa.

\section{MANUSKRYPTY I PIERWSZE EDYCJE DRUKOWANE}

Znany ze współczesnych edycji krytycznych tekst Corpus Theognideum opiera się na tzw. manuskrypcie A (Paris, Bibl. Nat. Suppl. Gr. 388): „uroczej książeczce pergaminowej" - jak pisze Douglas Young ${ }^{9}$ - jednym z najważniejszych rękopisów bizantyńskich ${ }^{10}$, stworzonym prawdopodobnie w $\mathrm{X}$ wieku po Chr. Manuskrypt A wpisuje się tym samym w barwną historię Bizancjum,

\footnotetext{
${ }^{6}$ Giovanni CERRI, „Il significato di 'sphregís' in Teognide e la salvaguardia dell'autenticità testuale nel mondo antico”, Quaderni di Storia 33(1991): 27: ,,[...] la poesia memorizzata non è sentita come testo di cui rispettare la lettera e la paternità, bensi come un patrimonio comune, da riutilizzare e rielaborare con la massima libertà, in vista delle sempre diverse occasioni di canto".

${ }^{7} \mathrm{~W}$ tym miejscu chciałbym uprzejmie podziękować Recenzentom za liczne wskazówki bibliograficzne oraz surową krytykę niektórych założeń, które przyjąłem w pierwszej wersji artykułu.

${ }^{8}$ Hans-Georg GADAMER, „Pomiędzy fenomenologią a dialektyką - próba samokrytyki," przeł. Andrzej Przyłębski, w Andrzej PrzYŁęBSKI, Gadamer (Warszawa: Wiedza Powszechna, 2006), 250; Hans-Georg GADAMER, „Uniwersalność problemu hermeneutycznego,” przeł. Andrzej Przyłębski, w PrZYŁęBSki, Gadamer, 144.

${ }^{9}$ Douglas YounG, „A Codicological Inventory of Theognis Manuscripts (with Some Remarks on Janus Lascaris' Contamination and the Aldine Editio Princeps)", Scriptorium 7, nr 1(1953): 4: „A charming small vellum book of 113 leaves, 157x125 mm., 24 lines a page, probably Xth century, in a hand close to that of the grammatical miscellany Barocci 50".

${ }^{10}$ Filippo RonCOni, „Il Paris suppl. gr. 388 e Mosé del Brolo da Bergamo”, Italia Medioevale e umanistica 47(2006): 1.
} 
stanowiąc jeden $\mathrm{z}$ wielu dowodów na wzrastające w tym czasie (nie bez związku z rządami Konstantyna VII Porfirogenety ${ }^{11}$ ) zainteresowanie dziedzictwem kulturowym Grecji na konstantynopolitańskim dworze ${ }^{12}$. Oprócz Teognisa w kodeksie znalazł się także Dionizjos Periegeta, ponadto tekst obu autorów opatrzony został komentarzem w języku łacińskim, zdaniem Younga powstałym w XII bądź XIII wieku ${ }^{13}$. Początkowe miejsce pobytu manuskryptu pozostaje zagadką, wiadomo jednak, że niedługo po 1732 r. Francesco Scipione Maffei, wszechstronnie wykształcony badacz kultury antycznej, kolekcjoner zabytków, ponadto członek Royal Society, przekazał go Bibliotece Kapitulnej w Weronie (Biblioteca Capitolare di Verona), skąd w 1797 r. trafił do Paryża ${ }^{14}$. Przenosinom dzieła zawdzięczamy pierwsze jego wydanie książkowe: Theognidis Elegi, opublikowane przez Augusta Immanuela Bekkera (Lipsiae 1815) ${ }^{15}$.

Wartość manuskryptu A wynika nie tylko z tego, że powstał dużo wcześniej od innych rękopisów, tym samym w mniejszym stopniu był narażony na błędy kopistów, lecz także z faktu, że jako jedyny zawiera tzw. księgę drugą: zbiór wierszy o wyraźnie erotycznym charakterze, który - jak przypuszczał Jean Carrière - został wycięty ze zbioru poematów w czasach chrześcijańskich, zebrany następnie w oddzielnym „załączniku” (nazywanym księgą drugą) ${ }^{16}$. To, że atmosfera obyczajowa $\mathrm{w}$ średniowiecznym Bizancjum sprzyjała podobnej cenzurze $^{17}$, potwierdza Suda, leksykon z X wieku, gdzie o Corpus Theognideum

${ }^{11}$ Leighton D. Reynolds, Nigel G. Wilson, Scribes and Scholars: A Guide to the Transmission of Greek and Latin Literature (Oxford: Oxford University Press, 2013), 66-67.

${ }^{12} \mathrm{~W}$ podobnym czasie powstał także manuskrypt Barocci 50 zawierający teksty przypisywane Muzajosowi, redakcja Antologii Palatyńskiej (REynolds, Wilson, Scribes and Scholars, 67), a także - o czym przypomina Lech Trzcionkowski - kodeks zawierający Corpus Hermeticum (,co wskazuje, że podejmowano wówczas wysiłek porządkowania pogańskiej literatury religijnej”), IDEM, Bios - Thanatos - Bios. Semiofory orfickie z Olbii i kultura polis (Warszawa: Sub Lupa 2013), 10.

${ }^{13}$ Zob. Ronconi, "Il Paris suppl. gr. 388”, 2. Być może w datacji tych łacińskojęzycznych gloss kryje się wskazówka dotycząca dalszych losów pergaminu: manuskrypt mógł trafić do Europy wraz z napaścią na Konstantynopol w ramach IV Wyprawy Krzyżowej w 1204 r.

${ }^{14}$ Young, „A Codicological Inventory”, 4.

${ }^{15}$ Który błędnie nadał kodeksowi nazwę „Mutinensis”, sugerującą związek rękopisu z miastem Modeną bądź wskazującą północne Włochy jako miejsce jego powstania.

${ }^{16}$ Jean CARRIERE, Theognis de Mégare. Étude sur le Recueil élégiaque attribué à ce poète (Paris: Bordas, 1948). Contra: Ewan BowIE, „An Early Chapter in the History of the Theognidea", w Approaches to Archaic Poetry, red. Xavier Riu, Jaume Pòrtulas (Messina: Dipartimento di Scienze dell'Antichità, 2012), 123-132, który uważa, że księga pierwsza i druga stanowiły oddzielne antologie, powstałe jeszcze w epoce klasycznej, zob. niżej, przypis 53.

${ }^{17}$ Zagadnienie stosunku do seksualności w czasach bizantyńskich, zwłaszcza do homoseksualizmu, jest rzekomo niejednoznaczne: jak stwierdza Stephen HALLIwELL, „Foreword: The Book and its Author", w Kenneth Dover, Greek Homosexuality (London-New York: Bloomsbury, 2016), XXIIIXXIV, istnieją dowody na utrzymywanie się „greckiego homoseksualizmu” w czasach Bizancjum. 
powiada się: „wśród tych [elegii] rozrzucone zostały niegodziwości ( $\mu$ ıрíaı)

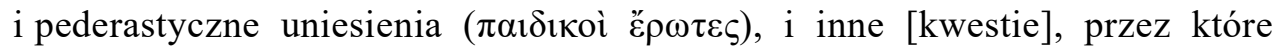
życie odwraca się od cnoty"18.

Drugim najstarszym przedstawicielem tej samej „gałęzi” transmisji tekstu jest pochodzący z początku XIV wieku rękopis O (Vaticanus, gr. 915) ${ }^{19}$. Kolekcja ta, zdaniem Younga, jest nieuporządkowana (much disordered), pisana ręką niechlujnego skryby ${ }^{20}$, zaś jak stwierdził Wilhelm Studemund kopista stworzył go „albo dla własnych potrzeb, albo dla użytku jakiegoś ubogiego uczonego"21 (według Douglasa Younga, był nim bizantyński historyk Nicefor Gregoras ${ }^{22}$, który z rękopisu korzystał prawdopodobnie dla potrzeb swojej działalności dydaktycznej). Wszystkie inne rękopisy wykazują ścisły związek z rękopisem watykańskim O, choć różnią się ilością wersów ${ }^{23}$.

Nie znalazłem rzetelnych studiów rozwiązujących ten dylemat, jak można jednak wnosić, analizując ówczesne przepisy legislacyjne regulujące sferę seksualną czy terminologię (zob. William A. PERCY, „Byzantine Empire”, w Encyclopedia of Homosexuality, t. I, red. Wayne R. Dynes (New York: Garland Publishing, 2016), 180-183), stosunek seksualny między mężczyznami (nazywany $\pi \alpha 1 \delta \varepsilon \rho \alpha \sigma \tau i \alpha)$ stanowił temat tabu i był postrzegany skrajnie negatywnie.

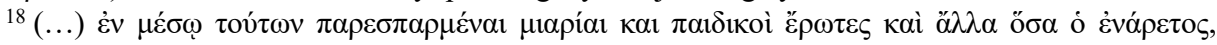
Suda, s.v. Theognis, według wydania Elegy and Iambus, t. I, ed. John M. Edmonds (Cambridge, Mass.: Harvard University Press, 1931). (Przekłady, o ile nie wskazuję nazwiska tłumacza, są mojego autorstwa). Jak przypuszcza Andrew LEAR, „The pederastic elegies and the autorship of the Theognidea", The Classical Quarterly 61, nr 2(2011): 380, twórca powyższego hasła opierał się na wersji Corpus Theognideum niepoddanej jeszcze cenzurze obyczajowej - sugerowałoby to, że w X wieku istniały inne, „starsze” manuskrypty bądź odpisy, usunięcie elegii zebranych następnie w księdze drugiej nastąpiło zaś mniej więcej w tym okresie. Dla kontrastu, w monumentalnej Anthologia graeca, utworzonej ok. 1300 r. w kręgu Maksyma Planudesa, nie występowały już jakiekolwiek elegie erotyczne z księgi drugiej Corpus Theognideum, zob. Nigel G. WILSON, Scholars of Byzantium (LondonCambridge, Mass.: Duckworth/Medieval Academy of America), 237-238.

${ }^{19}$ Jean CARrIERE, „Introduction à Théognis”, Pallas 18(1971): 22; YounG, „A Codicological Inventory”, 4-6. Na temat manuskryptu (MS Vat. Gr. 915) zob. Filippomaria PONTANI, „The World on a Fingernail: An Unknown Byzantine Map, Planudes, and Ptolemy”, Traditio 65(2010): 177-200.

${ }^{20}$ YounG, „A Codicological Inventory”, 4: ,[written] in an ugly learned hand”.

${ }^{21}$ Wilhelm STUdEMUND, „De Theognideorum memoria libris manu scriptis servata,” w IDEM, Index lectionum in Universitate litterarum Vratislaviensi (Breslau: Typis Universitatis, 1889), 8: „(...) aut suum in usum aut pauperis alicuius hominis docti in usum corpus illud poetarum maxime epicorum et lyricorum videtur conscripsisse".

${ }^{22}$ Young, „A Codicological Inventory”, 6, łączy rękopis O z postacią Gregorasa poprzez inny manuksrypt (zbiór fragmentów Pal. Graec. 129). Contra: Ihor ŠEVČENKO, „Some Autographs of Nicephorus Gregoras”, Zbornik radova 8(1964): 435-450. Douglas Young wskazuje także na obecność w części manuskryptu zawierającej elegie Teognisa (folia 25-34) poprawek autorstwa bizantyńskiego uczonego Maksyma Planudesa, IDEM, ,ad Theognidem adiectis”, w Theognis. Ps.-Pythagoras. Ps.-Phocylides. Chares. Anonymi Aulodia. Fragmentum teliambicum, ed. Douglas Young (Lipsiae: Teubner, 1961), VIII, zob. także PONTANI, „The World on a Fingernail”, 189-190.

${ }^{23}$ Wyjątkiem jest jedynie manuskrypt K, nazywany Marcianus 317 lub gr. 522, który jest bezpośrednią kopią rękopisu $\mathrm{O}$. 
W XV wieku Teognis musiał być już autorem popularnym w Europie: istnieje spora grupa rękopisów (rękopis X znajdujący się w British Museum, rękopisy paryskie gr. 2008, 2739, 2866, 2891, watykański Barberinianus gr. 128 , Vaticanus gr. 63 oraz gr. 1388) powstałych w tym okresie. Niektóre z nich stanowią świadectwo ożywionego zainteresowania starożytnością w środowiskach dworskich, przejaw mody na czytanie i posiadanie dzieł antycznych oraz ślad aktywności legendarnych erudytów i humanistów wczesnorenesansowych. Dość wspomnieć o rękopisie paryskim gr. 2833 sporządzonym przez Johannesa Lascarisa, zawierającym fragmenty Teokryta, Teognisa oraz Hezjoda. Rękopis stanowił zapewne kopię innego dzieła - zaginionego korpusu greckich autorów należącego do biblioteki Medyceuszy i stworzonego na zamówienie Lorenzo di Piero de Medici, Wawrzyńca Medyceusza ${ }^{24}$. Można zatem powiedzieć, mimo skąpych źródeł i licznych pytań związanych $\mathrm{z}$ historią transmisji oraz recepcji Corpus Theognideum, że w XV wieku Teognisa wydawano w formie najbardziej ekskluzywnych manuskryptów tworzonych z myślą o największych bibliotekach europejskich, łączono w kodeksach z innymi autorami, powielano i przepisywano. Zainteresowanie tym zbiorem wśród elit intelektualnych Włoch, zwłaszcza elit Florencji, potwierdzają liczne źródła.

Kopiowanie książek w XV wieku nabiera zupełnie innej dynamiki za sprawą „rewolucji Gutenberga” ${ }^{25}$. Umasowienie produkcji manuskryptów - powoli przybierających postać współcześnie rozumianej książki - pozwoliło także na upowszechnienie autorów antycznych, w tym poematów przypisywanych Teognisowi. W 1495 r. Corpus Theognideum wydano drukiem ${ }^{26}$. Uczynił to Aldo Manuzio, właściciel założonego rok wcześniej domu wydawniczego, wenecjanin utrzymujący kontakty z uczonymi z całych Włoch i Europy, w tym także z Johannesem Lascarisem, twórcą wyżej opisanego rękopisu paryskie$\mathrm{go}^{27}$. My zaś dochodzimy tym sposobem do momentu historii transmisji Corpus

${ }^{24}$ Edmund Fryde, Humanism and Renaissance Historiography (London: Hambledon Press, 1983), 210. Nawiązania do Teognisa znajdujemy także u Lorenzo Pisano, w pracy De amore (fr. 30), powstałej między 1450 a 1460 r. (za: Amos Edelheit, Scholastic Florence: Moral Psychology in the Quattrocento (Leiden: Brill, 2014), 273-274), a nawet u Erazma z Roterdamu (Christopher CelenZA, Piety and Pythagoras in Renaissance Florence: The Symbolum Nesianum (Leiden-Boston-Köln: Brill, 2001), 66).

${ }^{25}$ Zob. nt. Elizabeth L. EISENSTEIN, Rewolucja Gutenberga, przeł. Henryk Hollender (Warszawa: Prószyński i Ska, 2004).

${ }^{26}$ Wydanie zawierało także Teogonię oraz Prace $i$ dnie Hezjoda, utwory Fokylidesa oraz Teokryta.

${ }^{27}$ Manuzio w 1494 r. wydał stworzony przez niego podręcznik gramatyki łacińskiej i greckiej - była to zresztą pierwsza książka opublikowana przez włoskiego wydawcę, zob. Will DuRANT, 
Theognideum, w którym nośnik tekstu pozwala zapomnieć o problemie ciągłości tradycji: powszechność oraz wielość książek drukowanych, choć niezwalniająca badacza z troski o śledzenie błędów w tekście czy pytań o kontekst powstania danego wydania, przenosi punkt ciężkości analiz na zupełnie inny tor.

Pobieżne porównanie rękopisu O z późniejszymi wersjami tekstu ukazuje postępującą pracę „ulepszania” tekstu Teognisa, która zmierza do usunięcia powtórzeń oraz rzekomych błędów. Każdy kolejny manuskrypt czy rękopis różni się od poprzedniego nie tylko przypadkowymi błędami kopistów, lecz zdaje się ilustrować sytuację opisaną przez Benedetto Bravo: „kopista mając przed oczyma nie oryginał a kopię i wiedząc, że teksty przepisywane ulegają deformacjom, nie chce kopiować biernie, lecz modyfikuje świadomie tekst we wszystkich tych ustępach, które słusznie lub niesłusznie wydają mu się zepsute, w celu przywrócenia formy pierwotnej”"28. Tę tendencję, jak zauważa Jean Carrière, można zresztą dostrzec już na etapie rękopisu watykańskiego, z którego zniknął (obecny w rękopisie A) dwuwiersz $332 \alpha-323 \beta^{29}$. Oprócz powtórzeń kolejni kopiści starali się wyeliminować „błędne” - z perspektywy dialektu attyckiego - formy jońskie, zastępując na przykład zaimek-enklitykę $\tau o \imath$ (w. 655 manuskryptu A) powszechniejszym wariantem oor

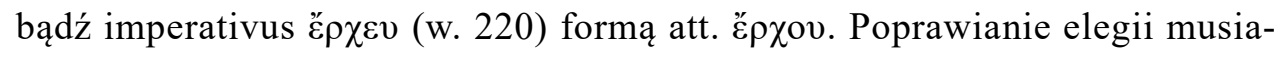
ło zresztą rozpocząc się jeszcze przed powstaniem kluczowego manuskryptu A, tekst rękopisu jest bowiem pełen form, które pod względem fonetycznym bądź morfologicznym właściwe są dla dialektu attyckiego (w opozycji do literackiego dialektu jońskiego ${ }^{30}$.

Wprowadzane do oryginalnego tekstu zmiany - powstałe na przestrzeni zaledwie czterech wieków dzielących rękopis A od rękopisu O - ukazują, jak daleko zniekształcający dla tekstu był w średniowieczu proces jego transmisji.

The Renaissance: A History of Civilization in Italy from 1304-1576 A.D. (New York: Simon \& Schuster, 1953), 316; Stephen Scully, Hesiod's Theogony: From Near Eastern Creation Myths to Paradise Lost (Oxford-New York: Oxford University Press, 2015), 163.

${ }^{28}$ Benedetto Bravo, „Krytyka tekstu”, w Vademecum historyka Starożytnej Grecji i Rzymu, t. I, red. Ewa Wipszycka (Warszawa: Państwowe Wydawnictwo Naukowe, 1982), 129-130.

${ }^{29}$ CARRIÈRE, ,Introduction à Théognis”, 23.

${ }^{30} \mathrm{~Np}$. tryb rozkazujący czasu teraźniejszego strony medialnej na -ov (w. 129, 171, 217, 220, $465,633,1179,1226)$, aor. med. 2 os. sg. -ov $(454,1362)$, zakończenie gen. sg. -ovৎ zamiast joń. -

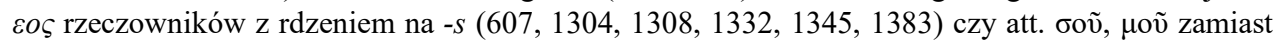
joń. $\sigma \varepsilon \tilde{v}$ czy $\mu \varepsilon \tilde{v}(100,262,414,697,969,1203,1205,1239,1240,1340,1342)$. Attycyzmy w Corpus Theognideum pod względem prozodycznym na ogół pokrywają się z ekwiwalentami jońskimi: zastąpienie oryginalnych (?) form jońskich formami attyckimi było zatem możliwe bez naruszania metrycznego porządku elegii, co mogło stanowić dodatkową zachętę dla kopistów do „ulepszania” tekstu. Zobacz na ten temat: Holger Friis JoHANSEN, „A Poem by Theognis (Thgn. 1938), part II", Classica Et Mediaevalia 44(1993): 5-29. 
Interpolacje pokazują również, jak ryzykowna jest każda próba dowodzenia bądź podważania autentyczności Corpus Theognideum na podstawie analizy językoznawczej.

\section{NARODZINY PYTANIA O JEDNOŚĆ AUTORSKĄ: PIERWSZE EDYCJE KRYTYCZNE}

Wspomniana wyżej popularyzacja wynalazku Gutenberga zbiegła się w czasie z zupełnie inną „rewolucją": zmianą paradygmatu myślenia o historii, prowadzącą do wykształcenia metod krytyki źródeł historycznych. Ruchy reformacyjne, wraz z kluczowym dla nich ideałem powrotu do początków Kościoła, wyrażały się - jak pokazuje to Krzysztof Pomian ${ }^{31}$ - poprzez spory teologiczne i prawne, przybierające niekiedy formę podważania autentyczności dokumentów kościelnych. Wątpliwości związane z rzekomym ofiarowaniem Cesarstwa Zachodniego papieżowi (przekonaniem uzasadnianym treścią nieautentycznej „Donacji Konstantyna”) 32 stały się okazją do wypracowania nie tylko podstawowych metod krytycznych, lecz także „przytomności” w myśleniu o przeszłości, wykształcenia swoistego „zmysłu hermeneutycznego" ${ }^{33}$.

Oczywiście, „hermeneutyka” w wypadku tradycji renesansowej jest swoistym terminus post quem, anachronizmem nadającym świadomości tej epoki cechy dla niej obce. Tym, co znamionuje hermeneutykę, jest przyznanie, że nasze myślenie jest zapośredniczone przez oddziałującą na nas historię, że wszelkie wartościowanie przeszłości jest ściśle związane z tym, co dzieje się teraz i co wywiera na nas wpływ. Tymczasem dla historyków renesansowych, jak pisze Krzysztof Pomian, „kryterium prawdy miało charakter wartościujący, [...] stwierdzenie faktu nie oddzieliło się jeszcze od oceny"34. Uwidacznia to stosunek ówczesnych myślicieli do starożytności, traktowanej jako „nieprzekraczalne maksimum" osiągnięć ludzkich. Antyczni autorzy stali się punktem odniesienia i niepodważalnym autorytetem, zaś historia - cyklicznym następstwem epok, spośród których czasy Grecji i Rzymu stanowiły cel, jaki należało ponownie osiągnąc $c^{35}$.

\footnotetext{
${ }^{31}$ Krzysztof Pomian, Przeszłość jako przedmiot wiedzy (Warszawa: Uniwersytet Warszawski, 2010).

${ }^{32}$ Zob. Pomian, Przeszłość jako przedmiot wiedzy, 92-93.

${ }^{33}$ Zob. Hans-Georg GADAMER, „Hermeneutyka podejrzana”, przeł. Przemysław Czapliński, Pamiętnik Literacki 83, nr 1(1992): 73.

${ }^{34}$ Pomian, Przeszłość jako przedmiot wiedzy, 110-111.

${ }^{35}$ Ibidem, 61, 73, zob. także Alicja KUCZYŃSKA, „Nostalgia jako projekt. U źródeł renesansowej filozofii zgody", Sztuka i filozofia 12(1996): 17-30.
} 
W tym kontekście historycznym, w otoczeniu nieufnych wobec dowodów przeszłości reformatorów religijnych, czczących czasy antyczne humanistów oraz drukowanych od blisko stu lat książek, Joachim Camerarius - we wstępie do własnej edycji elegii przypisywanych Teognisowi - w 1551 r. jako pierwszy poddał w wątpliwość autentyczność Corpus Theognideum ${ }^{36}$. Jak pisał, nie bez podziwu dla dorobku XVI-wiecznego edytora, Friedrich Gottlieb Welcker ${ }^{37}$ :

Camerarius doprowadził [dyskusję dotyczącą korpusu] do omówienia trudniejszych [zagadnień] - takich, które nie wiązały się [bezpośrednio] z poetą, oraz miejsc, którymi [dotąd] niezbyt chętnie zajmowali się współcześni edytorzy. Jako pierwszy pojął, że autentyczne dzieło (genuinum opus) nie pochodzi od jednego poety; nie pozostawił też nietkniętym żadnego miejsca, w którym występowało uszkodzenie (offensio), a jeśli [jakiejś] trudności nie mógł rozstrzygnąć, oznajmiał przynajmniej, że dzieło interpretacji przedsięwziął tak mądrze i z taką pilnością, aby żaden inny edytor [podchodząc do] tego zadania (ad hanc proviniam) nie mógł się z nim równać, i aby jego uwagi, dodane do [tekstu] poety w formie komentarza i zmierzające do rozwiązania [danej kwestii], [...] można było czytać z korzyścią.

Camerarius skwapliwie wykorzystał wypracowane przez poprzedników metody filologicznej analizy tekstów i „badań antykwarycznych”, doskonale rozumiał konieczność korzystania z różnych źródeł przy pracy nad jednym tekstem oraz poszukiwania wskazówek dotyczących autentyczności dzieła bądź jego fragmentów także poza nim samym. Opierając się na Arystotelesie, Stobajosie oraz Plutarchu, kilkakrotnie cytujących fragmenty bliskie niektórym wersom z Corpus Theognideum i niekiedy podpisujących je imionami innych autorów ${ }^{38}$, dążył do odnalezienia w korpusie tego, co nieautentyczne. Podsumował wyniki swoich analiz następująco:

${ }^{36}$ Ernest L. Highbarger, „A New Approach to the Theognis Question”, Transactions and Proceedings of the American Philological Association 58(1927): 171 oraz Hendrik SELLE, Theognis und die Theognidea (Berlin-New York: Walter de Gruyter, 2008), 4. Selle zwraca uwagę także na wydanie Eliasa Vinetusa z 1543 r., który starał się usunąć powtórzenia z tekstu oraz wersy przypisywane przez inne źródła Mimnermosowi, zob. wyżej, przyp. 2.

${ }^{37}$ Gottlieb Welcker, Theognidis Reliquiae (Francofurtum ad Moenum: Sumptibus et typis H.L. Broenneri, 1826), CXIV: „Plurimum autem contulit Camerarius ad difficiliorum, qui haud pauci huic poetae insunt, locorum explicationem, de qua recentiores editiores non magnopere laborarunt. Primus intellexit, non unius poetae genuinum opus se tractare; locum autem nullum, in quo aliquid esset offensionis, intactum reliquit; sed difficultates si tollere nequiret, indicavit saltem, et omnino tam prudenter diligenterque interpretis officio functus est, ut quantum ad hanc provinciam Theognidis editorum nemo ullus cum eo comparandus sit, et ut commentariii ejus, ad poetae aditum in scholas patefaciendum conscripti, [...] cum fructu legi possint".

${ }^{38}$ Doskonały przykład tej metody przedstawia zaproponowana przez badacza atrybucja fr. $467-$ 496. Camerarius, na podstawie Metafizyki Arystotelesa (Met. 1015a28, gdzie Arystoteles cytuje - ze zmianą jednego słowa - wers 472 zbioru, przypisując go Euenosowi), cały fr. 467-496 uznał za dzieło 
Jest więc oczywiste, że utwory ( $\check{\pi} \pi \eta)$ przypisywane Teognisowi są zbiorem różnych wierszy, spośród których te, które wydawały się zawierać jakąś nieprzyzwoitość ( $\alpha i \sigma \chi \rho \circ \lambda o \gamma i ́ \alpha)$, zostały [wcześniej] odłączone, w ich zaś miejsce wkomponowano inne [wersy]. I dlatego niezgodności są tak liczne, a te same [wiersze] na różne sposoby ( $\alpha v \alpha \pi \circ \lambda \eta \tau \iota \kappa \tilde{\omega} \varsigma)$ powtarzają się 39 .

Warto przyjrzeć się bliżej kontekstowi krytyki Camerariusa: jako osoba głęboko religijna, uczestnicząca $\mathrm{w}$ reformacji i zaprzyjaźniona z Filipem Melanchthonem, współtwórcą ruchu reformacyjnego i współpracownikiem Marcina Lutra ${ }^{40}$, uczony z niechęcią patrzył na niektóre fragmenty Corpus Theognideum, zwłaszcza te zawierające aluzje erotyczne; dla niego było oczywiste, że Teognis skomponował swój zbiór z myślą o wychowaniu młodzieży ${ }^{41}$. W konsekwencji przyjęcia tych radykalnych założeń-rozstrzygnięć, ustępy, które nie spełniały funkcji parenetycznej, uważał za nieautentyczne.

Po opublikowaniu manuskryptu A (w 1815 r. przez I. Bekkera, zob. wyżej) wątpliwości wokół jedności autorskiej, jak również metoda weryfikacji autentyczności elegii zaproponowana przez Camerariusa, nabrały rozmachu. Przy-

wspomnianego poety. W elegii 467-96 pojawia się inwokacja do Symonidesa, powtarzana w dwóch pozostałych fragmentach zbioru: 667-82 i 1341-50. Camerarius wyłącznie na tej podstawie rozszerzył atrybucję Euenosa na pozostałe dwa fragmenty. Jak zauważa Bernard KNox, „Theognis”, w The Cambridge History of Classical Literature, t. I, red. Patricia Easterling, Bernard Knox (Cambridge: Cambridge University Press, 1989), 96-97: „This structure is obviously shaky; everything depends on Aristotle's attribution of one line. But that line is not a very original observation - 'For everything forced on one by necessity is painful' - and even if the lines depend on each other, Euenos may be quoting Theognis [...]”; por. BowIE, „An Early Chapter in the History of the Theognidea”, 123-132.

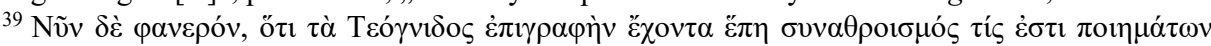

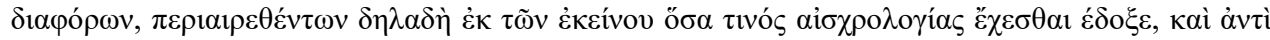

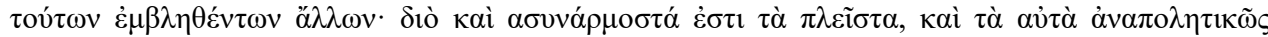
$\pi \alpha \lambda\lrcorner \lambda \lambda \mathrm{o} \gamma \varepsilon i \tau \alpha$. Cyt. za: SelLe, Theognis und die Theognidea, 198.

${ }^{40}$ Co ciekawe, Filip Melanchthon także interesował się Teognisem: był autorem szczegółowego opracowania Corpus Theognideum pt. Explicatio Sententiarum Theognidis, w którym wers po wersie analizował zachowane elegie, poszukując wątków wspólnych między dawną grecką mądrością a Ewangeliami, zob. Corpus Reformatorum, t. XIX (ed. Heinrich E. Bindseil, Brunsvigae: Halis Saxonum, 1853). Jak pisze Felix Mundt, słynny reformator bronił tradycji antycznej przed zarzutami o nieprzystawalność do doktryny chrześcijańskiej oraz ksiąg objawionych; twierdził, że „boskie światło" (lumen) znali już autorzy pogańscy, swą tezę uzasadniał zaś poprzez pogłębioną analizę starożytnych tekstów, takich jak zbiór elegii Teognisa, przedstawiając je jako ponadczasowe źródło przysłów moralno-filozoficznych, IDEM, „Melanchthon und Cicero. Facetten des Eklektizismus am Beispiel der Seelenlehre", w Der Philosoph Melanchthon, red. Frank Günter, Felix Mundt (Berlin-Boston: Walter de Gruyter, 2012), 158. Dodam, że Melanchthon doceniał również możliwości płynące z analizy różnic między chrześcijaństwem a czasami pogańskimi (jak pisał, „wiele może zostać zrozumiane, gdy zwrócimy uwagę na te odmienności (discrimina)", Explicatio Sententiarum Theognidis, 60).

${ }^{41}$ Ten sam zamiar przyświecał zresztą i Camerariusowi, który tworzył własne wydanie autorów antycznych z intencją przygotowania pomocy szkolnych - co sugeruje już tytuł zbioru, Libellus scolasticus utilis. 
czynił się do tego Fridericus Theophilus Welcker ${ }^{42}$ uważany za prawdziwego twórcę współczesnego sporu wokół „kwestii Teognidejskiej”. W zawartej na końcu rękopisu A drugiej księdze Welcker dostrzegł potwierdzenie intuicji Camerariusa: zbiór jest kolekcją elegii ułożoną wtórnie (w epoce bizantyńskiej), wbrew pierwotnej intencji autora. Zadaniem, jakie stoi przed współczesnymi badaczami, jest więc „uporządkowanie” poszczególnych fragmentów. Oczywiście, w podobnym przedsięwzięciu pomocne stanie się udzielenie odpowiedzi na pytanie o zamiary samego Teognisa: Welcker uznał, że kolekcja elegii $\mathrm{w}$ oryginalnej formie była zbiorem moralnych oraz politycznych refleksji, wszystkie inne treści zawarte w korpusie miały stanowić zatem późniejszy, niechciany wtręt ${ }^{43}$.

Corpus Theognideum faktycznie może sprawiać wrażenie niespójnego ${ }^{44}$ : $\mathrm{z}$ jednej strony zbiór jest pełen nośnych gnom i pouczeń skierowanych do ucznia Kyrnosa, z drugiej - nawiązań do konwencji sympozjum i zabaw biesiadnych, dyspozycji wykonawczych wskazujących na performatywny charakter elegii, jawnie erotycznych aluzji. Wychodząc od tej rzekomej dwuznaczności, narzucając na interpretację współczesną sobie wrażliwość, pragnąc ponadto widzieć w Teognisie pedagoga o nienagannej postawie etycznej, wszystkie fragmenty niewygodne dla własnej interpretacji Camerarius uznał za interpolacje. Przy użyciu metod krytyki tekstu dostarczonych przez ruchy reformacyjne niemiecki wydawca mógł podjąć się obrony wyidealizowanego obrazu poety: uratować Teognisa-pedagoga, jego rzekome wady zrzucając na zepsucie tekstu. Ten sam zarzut należy postawić XIX-wiecznym spadkobiercom metody Camerariusa: Welckerowi, który w Teognisie rozpoznał poetę pochłoniętego wyłącznie zagadnieniami moralnymi i politycznymi ${ }^{45}$,

42 Theognidis Reliquiae. Zob. HighbArger, „A New Approach to the Theognis Question”, 172; Giulio ColesAnti, Questioni teognidee. La genesi simposiale di un corpus di elegie (Roma: Edizioni di storia e letteratura, 2011), 2.

${ }^{43}$ Wyróżnił jako nieautentyczne: a) fragmenty innych autorów (Quae aliis poetis, s. LXXX); b) parodie (Parodiae, LXXX); c) pojedyncze dystychy (Epigrammata, XCV); d) utwory sympotyczne (Convivalia carmina, XCVI); e) kierowane do Polipaidesa (Quae Polypaedae, C); f) erotyczne (Musa puerilis, CII).

${ }^{44}$ Schrader, Concordantia Theognidea, 1; Selle, Theognis und die Theognidea, 29.

${ }^{45}$ Zob. także Poetae lyrici graeci, t. II (Lipsiae 1843) Theodora Bergka, który na podstawie analiz testimoniów z epoki klasycznej, przede wszystkim Izokratesa i Ksenofonta, uznał, że w IV wieku przed Chr. kolekcja (sylloge) elegii Teognisa, przynajmniej w formie bliskiej współczesnemu Corpus Theognideum, ,jeszcze nie istniała”; jak dodawał, „nic [nam] jednakże nie zabrania, abyśmy przeto założyli, że zbiór powstał niedługo później, [skomponowany z dzieł różnych] poetów elegijnych" 
Emilowi von Geyso, dla którego autor elegii był niemalże wychowankiem szkół filozoficznych ${ }^{46}$, czy Johannesowi Lucasowi, który uważał - na przekór publikacjom Nietzschego ${ }^{47}$ i van der Meya (Studia Theognidea, Leidae 1869), którzy jasno wykazali podobieństwa między księgą pierwszą i drugą - że elegie dodane do manuskryptu A stanowiły parodie, które miały służyć oczernieniu Teognisa poprzez przedstawienie go jako pederasty ${ }^{48}$.

Dla XIX-wiecznych badaczy stało się oczywiste, że Corpus Theognideum nie przedstawia nic „poza gruzami i skąpymi pozostałościami, należącymi nie do jednego, lecz do wielu poetów"49. Tymczasem, jak pisał Ulrich von Wilamowitz-Moellendorff, cała tradycja antyczna „przynosi nam tylko zgliszcza”: im dłużej badamy te przekazy, tym bardziej oczywista staje się ich fragmentaryczność ${ }^{50}$. Z tego względu tak istotne dla procesu interpretacji jest

(ibidem, 235: „nondum talis sylloge extabat. Sed nihil prohibet quominus existimemus non ita multo post has eclogas ex poetis elegiacis facta est").

${ }^{46}$ Studia Theognidea (Argentoratum Strasburg, 1892), zob. rozdz. I, „quae fuerit auctoritas Theognidis apud antiquos, imprimis apud philosoplios".

${ }^{47}$ Mam na myśli zwłaszcza ,pracę magisterską” (Valediktionsarbeit) Fryderyka Nietzschego zatytułowaną „O Teognisie z Megary” (De Theognide Megarensi), obronioną 7 września 1864 r. Zob. Robert Martin KeRR, „Preface”, w Friedrich NieTZSCHE, „De Theognide Megarensi. Nietzsche on Theognis of Megara. A bilingual edition” ([bmw], 2015) (dostęp: 21.12.2016, http://www. thenietzschechannel.com/works-unpub/youth/dtm-2015-kerr.pdf).

${ }^{48}$ Studia Theognidea (Berolini, 1893), 34: „Poeta enim amatorius si illud fecisset, sine dubio distichon non per se solum collocasset, sed cum versibus insequentibus in unum carmen conglutinasset”. Pomysł Lucasa na usprawiedliwienie obecności elegii erotycznych w zbiorze pojęciem „parodii” powtarza się jeszcze u Aurelio Perettiego, Teognide nella tradizione gnomologica (Pise: Librería Goliardica Editrice, 1953), gdzie rolę uzasadnienia pełni żydowski spisek (sic!) oraz „propaganda żydowskiego hellenizmu" (la paganda del giudaismo alessandrino, la manipolazone propagandistica del giudaismo alessandrino): to, że już Atenajos cytuje fragmenty korpusu o charakterze towarzyskim i erotycznym (w. 993-6, 997-1002) Peretti tłumaczy dostępnością w tym czasie źródeł z drugiej ręki, tj. żydowskich przekazów tworzonych z myślą o oczernieniu kultury greckiej (ibidem, 81-82 oraz 105-107; zwraca na to uwagę Douglas Young w recenzji książki „Review: Theognis. Teognide nella tradizione gnomologica by Aurelio Peretti”, The Classical Review 5, nr 1(1955): 35-37). Pojęcie parodii (pastiche) wykorzystuje także CARRIÈrE, Theognis de Mégare, 33, 99-103; IDEM, „Nouvelles remarques sur l'époque et sur le texte de Théognis”, Revue des Études Grecques 67 (1954): 48-49; contra: Theodore A. TARKOw, „Theognis 237-254: A Reexamination", Quaderni Urbinati di Cultura Classica 26(1977): 105-107.

${ }^{49}$ Theodor BergK, „Ueber der Kritik in Theognis”, Rheinisches Museum für Philologie 3(1845): 213: „[...] nichts als Trümmer und dürftige Reste, die nicht einmal einem, sondern verschiendenen Dichtern angehören".

${ }^{50}$ Ulrich von Wilamowitz-MoellendorfF, Greek Historical Writing and Apollo: Two lectures delivered before the University of Oxford, June 3 and 4, 1908, przel. Gilbert Murray (Chicago: Ares, 1979), 25: „The tradition yields us only ruins. The more closely we test and examine them, the more clearly we see how ruinous they are; out of ruins no whole can be built". Cytat omawia TRZCIONKOWSKI, Bios - Thanatos - Bios, 1-2. 
zachowanie właściwego dystansu. Przypadek Camerariusa uczy, że pozytywistyczna „bezzałożeniowość” na gruncie badań nad przeszłością nie istnieje, każdą analizę musi zaś poprzedzić refleksja nad „przesądami” (Vorurteile Gadamera), które mogłyby przesądzić o efekcie badań i charakterze interpretacji.

Współcześnie spór dotyczący jedności autorskiej zbioru - za sprawą uwzględnienia w badaniach oralnego modelu komunikacji - przestał być jednoznaczny z pytaniem o autentyczność tekstu. W perspektywie performatywno-pragmatycznej zaś Teognis to ktoś więcej niż tylko hipotetyczny autor kolekcji poetyckich fragmentów: to historyczny koncept, wpisana wewnętrznie w tekst instancja podmiotowa ${ }^{51}$, ponadto stały punkt odniesienia dla kolejnych wykonawców elegii „tradycji Teognidejskiej”52. Paradoksalnie, powody, dla których XIX-wieczni badacze odmawiali Corpus Theognideum autentyczności i tożsamości, dziś mogą stanowić o wyjątkowości tej kolekcji: tekstu, który przez wzgląd na praktykę wykonawczą pozostawał „w ruchu”, podatny na mimowolne bądź zamierzone zmiany, reinterpretacje i „przekodowania", składające się na świadectwo długiej, otwartej tradycji ${ }^{53}$.

\footnotetext{
${ }^{51}$ Por. NehAmas, „What an Author Is”, 688: ,[...] works generate the figure of the author manifested in them".

${ }^{52}$ Piszę o tym szerzej w artykule „Etyka i ideologia w Corpus Theognideum: uwagi o wieloznaczności pojęcia „dobry” w tradycji poetyckiej Teognisa z Megary” (w druku).

${ }^{53}$ Zob. wyżej, przyp. 4. Warto jednak podkreślić, że i to założenie stanowi przedmiot polemik. Pogląd forsowany jeszcze na początku lat pięćdziesiątych XX wieku (na przykład przez PeRETTIEGO, Teognide nella tradizione gnomologica), zgodnie z którym kolekcja znana z manuskryptów jest efektem pracy anonimowego bizantyńskiego kompilatora, upadł wraz z publikacją papirusów z IIIII wieku przed Chr. (P. Oxy. 2380, P. Berol. 21220, niedawno opublikowany P. Oxy. 5265), zawierających kilka sporych fragmentów elegijnych zestawionych w kolejności znanej z bizantyńskiego manuskryptu A oraz późniejszych rękopisów, zob. Roy KotansKY, „P. Berol $21220=$ Theognis, Elegiae I, 917-933”, Zeitschrift für Papyrologie und Epigraphik 96(1993): 1-5; James Brusuelas, ,5265. Theognis, Elegies 1117-40”, w The Oxyrhynchus Papyri, t. LXXXI, red. James Brusuelas, Chiara Meccariello (London: Egypt Exploration Society, 2016), 47-51; wiadomo zatem, że tekst w formie zachowanej na manuskryptach funkcjonował już w II wieku, nie jest jednak pewne, czy nie stanowi antologii skomponowanej z dzieł różnych autorów i niezależnych tradycji, powstałej w epoce hellenistycznej (jak wierzył Martin L. West, Studies in Greek Elegy and Iambus (Berlin-Boston: De Gruyter, 2011), 40-59) bądź jeszcze wcześniej, pod koniec V wieku przed Chr. (jak przekonuje BowIE, „An Early Chapter in the History of the Theognidea”, 121-146).
} 


\section{BIBLIOGRAFIA}

\section{TEKSTY ŹRÓDŁOWE, PRZEKŁADY, KOMENTARZE}

Elegy and Iambus. T. I, edited by John M. Edmonds. Cambridge, Mass.: Harvard University Press, 1931.

Melanchthon, Philippus. „Explicatio Sententiarum Theognidis”. W Corpus Reformatorum. T. XIX, edidit Heinrich E. Bindseil. Brunsvigae: Halis Saxonum, 1853.

Theognis. Ps.-Pythagoras. Ps.-Phocylides. Chares. Anonymi Aulodia. Fragmentum teliambicum, edited by Douglas Young. Lipsiae: Teubner, 1961.

\section{OPRACOWANIA}

BARTheS, Roland. „Śmierć autora”. Przełożył Michał Paweł Markowski. Teksty Drugie 1-2(1999): $247-251$.

BARTOL, Krystyna. „Elegia okresu archaicznego”. W Literatura Grecji Starożytnej, red. Henryk Podbielski, t. I, 323-350. Lublin: Towarzystwo Naukowe KUL, 2005.

BowIE, Ewan. „An Early Chapter in the History of the Theognidea”. W Approaches to Archaic Poetry, red. Xavier Riu, Jaume Pòrtulas, 121-146. Messina: Dipartimento di Scienze dell' Antichità, 2012.

Bravo, Benedetto. „Krytyka tekstu”. W Vademecum historyka Starożytnej Grecji i Rzymu, red. Ewa Wipszycka. T. I. Warszawa: Państwowe Wydawnictwo Naukowe, 1982.

BrusuelAS, James. „5265. Theognis, Elegies 1117-40”. W The Oxyrhynchus Papyri, edited by James Brusuelas, Chiara Meccariello, t. LXXXI, 47-51. London: Egypt Exploration Society, 2016.

CARriere, Jean. „Introduction à Théognis”. Pallas 18(1971): 3-30.

CARriERE, Jean. „Nouvelles remarques sur l'époque et sur le texte de Théognis”. Revue des Études Grecques 67(1954): 39-68.

CARRIERE, Jean. Theognis de Mégare. Étude sur le Recueil élégiaque attribué à ce poète. Paris: Bordas, 1948.

Celenza, Christopher. Piety and Pythagoras in Renaissance Florence: The Symbolum Nesianum. Leiden-Boston-Köln: Brill, 2001.

CERRI, Giovanni. „Il significato di 'sphregís' in Teognide e la salvaguardia dell'autenticità testuale nel mondo antico". Quaderni di Storia 33(1991): 21-40.

Colesanti, Giulio. Questioni teognidee. La genesi simposiale di un corpus di elegie. Roma: Edizioni di storia e letteratura, 2011.

Danielewicz, Jerzy, red. Antologia liryki hellenistycznej. Warszawa: Państwowe Wydawnictwo Naukowe, 2018.

Durant, Will. The Renaissance: A History of Civilization in Italy from 1304-1576 A.D. New York: Simon \& Schuster, 1953.

Edelheit, Amos. Scholastic Florence: Moral Psychology in the Quattrocento. Leiden: Brill, 2014.

Eisenstein, Elizabeth L. Rewolucja Gutenberga. Przełożył Henryk Hollender. Warszawa: Prószyński i Ska, 2004.

Dynes, Wayne R. Encyclopedia of Homosexuality. T. I. New York: Garland Publishing, 2016. 
FigueIRA, Thomas J. i Gregory Nagy, ed. Theognis of Megara. Poetry and the Polis. Baltimore: Johns Hopkins University Press, 1984.

FoucAult, Michel. „What Is an Author?” Translated by Josué V. Harari. W Textual Strategies: Perspectives in Post-Structuralist Criticism, edited by Josué V. Harari, 141-160. Ithaca, N.Y.: Cornell, 1979.

FRYDE, Edmund. Humanism and Renaissance Historiography. London: Hambledon Press, 1983.

GADAmER, Hans-Georg. „Hermeneutyka podejrzana”. Przełożył Przemysław Czapliński. Pamiętnik Literacki 83, nr 1(1992): 73.

GADAMER, Hans-Georg. „Poezja i interpretacja”. Przełożyła Małgorzata Łukasiewicz. Pamiętnik Literacki 68, $\mathrm{nr}$ 4(1977): 301-307.

GADAMER, Hans-Georg. „Pomiędzy fenomenologią a dialektyką - próba samokrytyki”. Przełożył Andrzej Przyłębski. W Andrzej PrzyŁęBSKI, Gadamer, 248-271. Warszawa: Wiedza Powszechna, 2006.

GADAmER, Hans-Georg. „Uniwersalność problemu hermeneutycznego”. Przełożył Andrzej Przyłębski. W Andrzej PrZYŁĘBSKI, Gadamer, 141-155. Warszawa: Wiedza Powszechna, 2006.

Halliwell, Stephen. „Foreword: The Book and its Author”. W Kenneth Dover, Greek Homosexuality, VII-XXVIII. London-New York, NY: Bloomsbury, 2016.

HighBARGer, Ernest L. „A New Approach to the Theognis Question”. Transactions and Proceedings of the American Philological Association 58(1927): 170-198.

JohAnsen, Holger Friis. „A Poem by Theognis (Thgn. 19-38), part II”. Classica Et Mediaevalia 44(1993): 5-29.

KeRR, Robert Martin. „Preface”. W NiEtzSChE, Friedrich. „De Theognide Megarensi. Nietzsche on Theognis of Megara. A bilingual edition" ([bmw], 2015) (dostęp: 21.12.2016, http://www.the nietzschechannel.com/works-unpub/youth/dtm-2015-kerr.pdf).

Knox, Bernard. „Theognis”. W The Cambridge History of Classical Literature, edited by Patricia Easterling, Bernard Knox, 95-105. Cambridge: Cambridge University Press, 1989.

KotAnsky, Roy. „P. Berol 21220 = Theognis, Elegiae I, 917-933”. Zeitschrift für Papyrologie und Epigraphik 96(1993): 1-5.

KuCZYŃSKA, Alicja. „Nostalgia jako projekt. U źródeł renesansowej filozofii zgody”. Sztuka i filozofia 12(1996): 17-30.

LEAR, Andrew. „The pederastic elegies and the autorship of the Theognidea”. The Classical Quarterly 61, nr 2(2011): 378-393.

Mundt, Felix. „Melanchthon und Cicero. Facetten des Eklektizismus am Beispiel der Seelenlehre”. W Der Philosoph Melanchthon, red. Frank Günter i Felix Mundt, 147-171. Berlin-Boston: de Gruyter, 2012.

Nehamas, Alexander. „What an Author Is”. The Journal of Philosophy 83, nr 11(1986): 685-691.

PERCY, William A. „Byzantine Empire”. W Encyclopedia of Homosexuality, edited by Wayne R. Dynes, t. I, 180-183. New York: Garland Publishing, 2016.

Peretti, Aurelio. Teognide nella tradizione gnomologica. Pise: Librería Goliardica Editrice, 1953.

Pomian, Krzysztof. Przeszłość jako przedmiot wiedzy. Warszawa: Uniwersytet Warszawski, 2010.

PONTANI, Filippomaria. „The World on a Fingernail: An Unknown Byzantine Map, Planudes, and Ptolemy”. Traditio 65(2010): 177-200.

PRZYŁĘBSKI, Andrzej. Gadamer. Warszawa: Wiedza Powszechna, 2006. 
Reynolds, Leighton D. i Nigel G. Wilson. Scribes and Scholars: A Guide to the Transmission of Greek and Latin Literature. Oxford: Oxford University Press, 2013.

Ricoeur, Paul. Język, tekst, interpretacja. Przełożył Piotr Graff. Warszawa: Państwowe Wydawnictwo Naukowe, 1989.

Ronconi, Filippo. „Il Paris suppl. gr. 388 e Mosé del Brolo da Bergamo”. Italia Medioevale e umanistica 47(2006): 1-27.

Selle, Hendrik. Theognis und die Theognidea. Berlin-New York, NY: Walter de Gruyter, 2008.

Scully, Stephen. Hesiod's Theogony: From Near Eastern Creation Myths to Paradise Lost. Oxford-New York, NY: Oxford University Press, 2015.

SCHRADER, Carlos. Concordantia Theognidea. Hildesheim-Zürich-New York: Olms-Weidmann, 2002.

SKARBEK-KAZANECKI, Jan. „Grecki symposion jako przestrzeń dyskursu filozoficznego: Ksenofanes i krytyka tradycji poetyckiej”. Tekstualia 56, nr 1(2019): 35-52.

ŠEVČENKO, Ihor. „Some Autographs of Nicephorus Gregoras”. Zbornik radova 8(1964): 435-450.

STUDEMUND, Wilhelm. „De Theognideorum memoria libris manu scriptis servata”. W IDEM. Index lectionum in Universitate litterarum Vratislaviensi. Breslau: Typis Universitatis, 1889.

TARKow, Theodore A. „Theognis 237-254: A Reexamination”. Quaderni Urbinati di Cultura Classica 26(1977): 99-114.

TrZCIONKOWSKI, Lech. Bios - Thanatos - Bios. Semiofory orfickie z Olbii i kultura polis. Warszawa: Sub Lupa, 2013.

UniŁowski, Krzysztof. Granice nowoczesności. Proza polska i wyczerpanie modernizmu. Katowice: Uniwersytet Śląski, 2006.

VetTA, Massimo. „Commento”. W Teognide, Libro Secondo. Introduzione, testo critico, traduzione e commento, ed. Massimo Vetta. Roma: Edizioni dell'Ateneo, 1980.

Welcker, Gottlieb. Theognidis Reliquiae. Francofurtum ad Moenum: Sumptibus et typis H.L. Broenneri, 1826.

Wilamowitz-MoellendorfF, Ulrich von. Greek Historical Writing and Apollo: Two lectures delivered before the University of Oxford, June 3 and 4, 1908. Translated by Gilbert Murray. Chicago, IL: Ares, 1979.

WiLson, Nigel G. Scholars of Byzantium. London-Cambridge, Mass.: Duckworth/Medieval Academy of America, 1996.

YounG, Douglas. „A Codicological Inventory of Theognis Manuscripts (with Some Remarks on Janus Lascaris' Contamination and the Aldine Editio Princeps)". Scriptorium 7, nr 1(1953): 3-36.

Young, Douglas. „ad Theognidem adiectis”. W Theognis. Ps.-Pythagoras. Ps.-Phocylides. Chares. Anonymi Aulodia. Fragmentum teliambicum, edited by Douglas Young. Lipsiae: Teubner, 1961

Young, Douglas. „Review: Theognis. Teognide nella tradizione gnomologica by Aurelio Peretti”. Recenzja Teognide nella tradizione gnomologica Aurelio Peretti'ego. The Classical Review 5, nr 1(1955): 35-37. 


\title{
PROBLEM AUTENTYCZNOŚCI CORPUS THEOGNIDEUM W ŚWIETLE HISTORII JEGO TRANSMISJI: MANUSKRYPTY I PIERWSZE EDYCJE KRYTYCZNE
}

\section{Streszczenie}

Corpus Theognideum stanowi największy zabytek wczesnogreckiej poezji i jeden z niewielu tekstów tego okresu, który przetrwał w bezpośrednim przekazie rękopiśmiennym. Forma, w jakiej znamy elegie, stała się źródłem trwającej blisko 200 lat dyskusji dotyczącej ich autentyczności. Celem tekstu było przedstawienie kluczowych dla problemu autentyczności Corpus Theognideum argumentów i uwag z perspektywy recepcji i jego transmisji w epoce bizantyńskiej i nowożytnej. Podjęcie tematu $\mathrm{w}$ przedstawionej tu formie zostało zainspirowane metodą hermeneutyczna Hansa-Georga Gadamera: na podstawie tej propozycji metodologicznej, autor dążył zarówno do zrozumienia świadectw przeszłości we właściwym kontekście historycznym, jak i do zrewidowania pewnych dogmatycznych interpretacji innych badaczy, opartych na powziętych z góry założeniach lub błędach.

Słowa kluczowe: Teognis; Theognidea; elegia; Kwestia Teognidejska; tradycja rękopiśmienna.

\author{
THE AUTHENTICITY OF THE CORPUS THEOGNIDEUM \\ THROUGHOUT THE HISTORY OF ITS TRANSMISSION: \\ MANUSCRIPTS AND THE FIRST PRINTED CRITICAL EDITIONS
}

Summary

Corpus Theognideum constitutes the largest anthology of poetry composed in the archaic or classical period as well as the only elegiac text that has been transmitted by medieval manuscripts. Nevertheless, the form in which we know this collection is provided an important basis for the discussion about its authenticity. The present article is the result of the examination of the problem both about the history of disputes concerning that subject, and about the reception of the Theognidean poems, traced in Byzantine, early modern and modern period. Special focus has been given to the manuscript tradition, e.g. the most ancient codex Paris suppl. gr. 388 and Vaticanus, gr. 915, which bears witness to the popularity of the Theognidean elegies in the Byzantine age. The very raising of the subject in the form presented above was inspired by HansGeorg Gadamer's hermeneutic method: based on this methodological proposal, the author sought to understand the evidence of the past in the proper historical context and to revise some dogmatic interpretations of other researchers; in this manner the author notes that the transmission of Corpus Theognideum is not really a solid foundation on which to build an argument about the falseness of the whole collection.

Key words: Theognis; Theognidea; elegy; the Theognidean question; the manuscript tradition. 